\title{
A Study on Chocolate Consumption in Prospective Teachers
}

\author{
Leyla Ozgen ${ }^{1}$ \\ ${ }^{1}$ Faculty of Vocational Education, Department of Food and Nutrition Education, Gazi University, Ankara 06500, Turkey \\ Correspondence: Leyla Ozgen, Faculty of Vocational Education, Department of Food and Nutrition Education, Gazi \\ University, Ankara 06500, Turkey.
}

Received: October 31, 2016

doi:10.11114/jets.v4i12.1955
Accepted: November 18, $2016 \quad$ Online Published: xx, 2016

URL: http://dx.doi.org/10.11114/jets.v4i12.1955

\begin{abstract}
This study was planned and conducted to determine the chocolate consumption habits of prospective teachers. The study population was comprised of students attending the Faculty of Education at Gazi University in Ankara and the sample consisted of 251 prospective teachers selected with simple random sampling. $96.4 \%$ and $3.6 \%$ of the prospective teachers were aged 19-35 and 25-30, respectively. In the study, $91.1 \%$ of the female prospective teachers and $75.3 \%$ of the male prospective teachers agreed with the statement chocolate consumption is good for cardiovascular diseases, while $4.1 \%$ of the female prospective teachers and $8.6 \%$ of the male prospective teachers disagreed. $77.1 \%$ of the female prospective teachers and $27.2 \%$ of the male prospective teachers agreed with the statement daily chocolate consumption lowers the blood pressure, while $15.3 \%$ of the female prospective teachers, and $55.6 \%$ of the male prospective teachers disagreed $\left(\mathrm{x}^{2}=58.583, \mathrm{p}<0.05\right) .59 .4 \%$ of the female prospective teachers, and $37.0 \%$ of the male prospective teachers agreed with the statement eating chocolate reduces my depression, while $35.9 \%$ of the female prospective teachers, and $46.9 \%$ of the male prospective teachers disagreed $\left(x^{2}=11.056, p<0.05\right)$. In addition, the female prospective teachers preferred to eat dark chocolate, chocolate with mixed nuts, flavored chocolate and liquor-filled chocolate more frequently than the male prospective teachers $(p<0.05)$. In conclusion, the female prospective teachers were more attentive and conscious than the male prospective teachers in their chocolate consumption.
\end{abstract}

Keywords: chocolate, cocoa, chocolate consumption, health benefit, prospective teacher

\section{Introduction}

Recent studies have emphasized the positive effects of chocolate on health. The raw material of chocolate is cocoa seeds produced by drying and fermenting the fruit of the "Theobroma cacao" tree. Cocoa seeds in chocolate contain lipids, fiber, minerals, polyphenols and antioxidants. The lipids found in the composition of cocoa are stearic and palmitic fatty acids (saturated fatty acids) and oleic fatty acid (monounsaturated fatty acid). In portions corresponding to $100 \mathrm{kcal}$, dark chocolate with $70 \%-85 \%$ cacao content contains $1.7 \mathrm{~g}$ fiber, while semi-sweet and milk chocolate contain $1.2 \mathrm{~g}$ and 0.6g fiber, respectively (Katz, Doughty, \& Ali, 2011). The majority of the fiber in cocoa is insoluble. Cocoa seeds contain the minerals magnesium, copper, potassium and calcium (Gibble, 2011). Cocoa is rich in flavonoids such as catechin, epicatechin, and procyanidins and has high antioxidant properties (Katz et al., 2011). The literature indicates that dark chocolate, milk chocolate and white chocolate should contain at least $18 \%$ cocoa butter, $14 \%$ nonfat cocoa solids and $35 \%$ total cocoa solids; $2.5 \%$ nonfat cocoa solids and $25 \%$ total cocoa solids; and $20 \%$ cocoa butter and $14 \%$ milk solids, respectively. In filled chocolate, the shell should be at least $25 \%$ of the total product weight and praline should contain at least $25 \%$ chocolate produced from a mixture of dark, milk, extra milk and white chocolate (Sokmen, 2005; Kaya, \& Sekeroglu, 2012). Chocolate should be bright and smooth in appearance and mahogany in color, have a rich flavor, make a cracking sound when broken and not crumble. With regard to taste, chocolate should immediately melt in mouth and have soft, crispy, velvety and creamy qualities (Beckett, 2008; Farzanmehr \& Abbasi, 2009; Anonymous, 2012). The flavanols present in the cocoa reduce oxidative stress, improve endothelial function and/or increase insulin resistance (Farid, Njike, Dutta, Ali, \& Katz, 2008; Grassi et al., 2012; Lilamand et al., 2014; Kerimi \& Williamson, 2015; Pazarbasi, 2015). Markus (2002) reported the consumption of dark chocolate had a calming effect and reduced depression by causing the brain to produce serotonin. Other studies indicated that the psychoactive effect of methylxantine or flavanols in cocoa improved cognitive function and mitigated mental fatigue (Katz et al., 2011; Scholey \& Owen, 2013). In addition, the polyphenols in chocolate protect cell membranes against free radicals, increase 
HDL-cholesterol levels and prevent plaque formation in artery walls (Hermann et al., 2006; di Giuseppe et al., 2008; Gibble, 2011; Martin, Goya, \& Ramos, 2013; Kwok et al., 2015). In one study it was reported that daily consumption of flavanol-rich cocoa products lowered blood pressure (Desch et al., 2010). However, in another study, the researchers concluded that daily chocolate consumption did not result in decreased blood pressure or reduced cardiovascular risk (Koli et al., 2015). On the other hand, chocolate has some adverse health effects. Due to the fat and sugar content in chocolate, excessive consumption could cause obesity and trigger diabetes (Greenberg \& Buijsse, 2013; Greenberg, 2015). However, another study reported dark chocolate consumption reduced liver enzyme level approximately $0.10 \mathrm{mg} / \mathrm{l}$ and the existence of an inverse relationship between dark chocolate consumption and insulin levels (Alkerwi, Sauvageot, Crichton, Elias, \& Stranger, 2016). Beckett (2008) emphasized that the list of ingredients and the amount of cocoa solids should be specified on the label as percentages. Ozgen (2004) expressed the importance of information such as ingredients, price, and production and expiration dates presented on the food label for healthy food selection.

\subsection{Importance of Research}

As the consumption of chocolate has both favorable and unfavorable effects on health, the significance of this study is the determination of the factors that affect the chocolate consumption of female and male prospective teachers. Chocolate is beneficial to health due to both the antioxidants and polyphenols in its composition and its stress relieving properties. However, it could also have negative health effects as excessive consumption of chocolate could lead to obesity due to its fat content. Therefore, the researcher believes the chocolate consumption of prospective teachers to be of import.

\subsection{Aim of Research}

This study was aimed at investigating chocolate consumption among prospective teachers. With this perspective, the researcher sought the answers to the following questions:

1. What are the properties they desire in chocolate?

2. Where do they use chocolate?

3. What are their reasons for consuming chocolate?

4. What are their considerations when buying chocolate?

5 . Which type of chocolate do they prefer?

6. What are the consumption frequencies of different types of chocolate?

\section{Materials and Methods}

\subsection{Participants}

The study population comprised the students attending the Faculty of Education at Gazi University in Ankara, Turkey and the sample consisted of 251 prospective teachers (170 female, 81 male) selected with simple random sampling. The study was carried out in the spring semester of the 2015-2016 academic years. $67.7 \%$ of the prospective teachers were female while $32.3 \%$ were male. $96.4 \%$ and $3.6 \%$ of the prospective teachers were aged 19-35 and 25-30, respectively.

\subsection{Data Collection Tools}

The study data were gathered with the questionnaire developed by the researcher through peer debriefing. The pilot administration was performed with 70 prospective teachers prior to the finalization of the questionnaire. The study employed the prospective teacher demographic form and the prospective teacher chocolate consumption questionnaire.

\subsubsection{Prospective Teacher Demographic Form}

The prospective teacher demographic form comprised demographic questions involving information such as the gender, age and education of the prospective teachers.

\subsubsection{Chocolate Consumption Habit Questionnaire}

The questionnaire comprises questions on desired properties, chocolate consumption, and reasons for eating chocolate, considerations when buying chocolate and preferred chocolate types. Content validity of the questionnaire was ensured through peer debriefing. After the pilot administration of the Chocolate Consumption Habit Questionnaire, items that were unclear were reviewed and the questionnaire was readied for proper administration. Each item in the questionnaire was evaluated with a 3-point Likert-type rating (1=Agree, 2=Moderately agree, 3=Disagree). The items were constructed as positive and negative statements, and negatively scored items were reverse coded. Positively increasing scores indicate a favorable increase in chocolate consumption habits. The overall Cronbach's alpha was computed as 0.659 . 


\subsection{Data Collection}

Official permission from the dean's office at the Faculty of Education in Gazi University was obtained for data collection. The administration of the questionnaire was carried out in the classrooms at the convenience of the professors and the questionnaire was administered to the prospective teachers in groups by the researcher. The prospective teachers were requested to participate in the study on a voluntary basis and were informed their information would remain confidential and the data would only be used for research purposes. Each data collection session lasted 15-20 minutes.

\subsection{Statistical Analysis}

Statistical Package for the Social Science SPSS 20.0 for Windows was used in data analysis. The desired properties and the areas of usage were evaluated in number and percentage distributions. The reasons for chocolate consumption with respect to gender was evaluated with a chi-square test, while the existence of a difference with respect to gender regarding the considerations when buying chocolate was investigated with an independent samples t-test. A chi-square test was conducted for the types of chocolate preferred by the prospective teachers. Statistical significance level was set at 0.05 .

\section{Results}

In the study, desired properties, chocolate consumption, reasons for eating chocolate, considerations when buying chocolate and preferred chocolate types were investigated among the prospective teachers (Table 1-4).

Table 1. Distribution of desired properties and chocolate consumption

\begin{tabular}{|c|c|c|}
\hline Desired properties & $\mathrm{n}$ & $\%$ \\
\hline \multicolumn{3}{|l|}{ Creaminess } \\
\hline Yes & 200 & 79.7 \\
\hline No & 51 & 20.3 \\
\hline \multicolumn{3}{|l|}{ Crispiness } \\
\hline Yes & 28 & 11.2 \\
\hline No & 223 & 88.8 \\
\hline \multicolumn{3}{|l|}{ Smooth texture } \\
\hline Yes & 106 & 42.2 \\
\hline No & 145 & 57.8 \\
\hline \multicolumn{3}{|l|}{ Milk Content } \\
\hline Yes & 111 & 44.2 \\
\hline No & 140 & 55.8 \\
\hline \multicolumn{3}{|l|}{ Cocoa Content } \\
\hline Yes & 63 & 25.1 \\
\hline No & 188 & 74.9 \\
\hline \multicolumn{3}{|l|}{ Area of usage } \\
\hline \multicolumn{3}{|l|}{ Cookie } \\
\hline Yes & 203 & 80.9 \\
\hline No & 48 & 19.1 \\
\hline \multicolumn{3}{|l|}{ Cake } \\
\hline Yes & 200 & 79.7 \\
\hline No & 51 & 20.3 \\
\hline \multicolumn{3}{|l|}{ Hot Chocolate } \\
\hline Yes & 171 & 68.1 \\
\hline No & 80 & 31.9 \\
\hline \multicolumn{3}{|l|}{ Ice Cream } \\
\hline Yes & 188 & 74.9 \\
\hline No & 63 & 25.1 \\
\hline
\end{tabular}

Table 1 shows that $79.7 \%, 44.2 \%, 42.2 \%, 25.1 \%$ and $11.2 \%$ of the prospective teachers were attentive to creaminess, milk content, smooth texture, cocoa content and crispiness, respectively. $80.9 \%, 79.7 \%$ and $74.9 \%$ used chocolate in baking cookies and cakes, and making ice cream, respectively, while $68.1 \%$ preferred to drink it as hot chocolate.

When Table 2 is examined, $91.1 \%$ of the female prospective teachers and $75.3 \%$ of the male prospective teachers agreed with the statement chocolate consumption is good for cardiovascular diseases. There was a statistically significant difference between groups with respect to gender $\left(x^{2}=12.056, p<0.05\right) .59 .4 \%$ of the female prospective teachers and $34.6 \%$ of the male prospective teachers agreed with the statement eating chocolate reduces my stress, while $18.2 \%$ of the female prospective teachers and $33.3 \%$ of the male prospective teachers disagreed. There was a statistically significant difference between groups with respect to gender $\left(x^{2}=14.044, p<0.05\right) .77 .1 \%$ of the female prospective teachers and $27.2 \%$ of the male prospective teachers agreed with the statement daily chocolate consumption lowers the blood pressure, while $15.3 \%$ of the female prospective teachers and $55.6 \%$ of the male 
prospective teachers disagreed. There was a statistically significant difference between groups with respect to gender $\left(\mathrm{x}^{2}=58.583, \mathrm{p}<0.05\right) .41 .2 \%$ of the female prospective teachers, and $24.7 \%$ of the male prospective teachers agreed with the statement eating chocolate helps me concentrate when studying, while $35.9 \%$ of the female prospective teachers and $46.9 \%$ of the male prospective teachers disagreed. There was a statistically significant difference between groups with respect to gender $\left(\mathrm{x}^{2}=6.511, \mathrm{p}<0.05\right) .59 .4 \%$ of the female prospective teachers, and $37.0 \%$ of the male prospective teachers agreed with the statement eating chocolate reduces my depression, while $35.9 \%$ of the female prospective teachers and $46.9 \%$ of the male prospective teachers disagreed. There was a statistically significant difference between groups with respect to gender $\left(x^{2}=11.056, p<0.05\right)$. However, the results with respect to gender were approximate for using chocolate to help bowel movement, to reduce fatigue and when working out, with no statistically significant difference between groups ( $p>0.05)$.

Table 2. Chi-square test results by gender for reasons of chocolate consumption

\begin{tabular}{|c|c|c|c|c|c|c|c|c|c|c|}
\hline \multirow[t]{2}{*}{$\begin{array}{l}\text { Reasons of consumption for } \\
\text { health }\end{array}$} & \multirow[t]{2}{*}{ Gender } & \multicolumn{4}{|c|}{$\begin{array}{l}\text { Moderately } \\
\text { agree }\end{array}$} & \multicolumn{2}{|c|}{ Disagree } & \multirow[t]{2}{*}{$x^{2}$} & \multirow[t]{2}{*}{$\mathrm{p}$} & \multirow[t]{2}{*}{ SD } \\
\hline & & $\mathrm{n}$ & $\%$ & $\mathrm{n}$ & $\%$ & $\mathrm{n}$ & $\%$ & & & \\
\hline \multirow{2}{*}{$\begin{array}{l}\text { Good for } \\
\text { cardiovascular diseases }\end{array}$} & 1 & 155 & 91.2 & 8 & 4.7 & 7 & 4.1 & \multirow{4}{*}{$\begin{array}{l}12.056 \\
14.044\end{array}$} & \multirow{4}{*}{$\begin{array}{l}.002 * \\
.002 *\end{array}$} & \multirow[b]{2}{*}{2} \\
\hline & 2 & 61 & 75.3 & 13 & 16.0 & 7 & 8.6 & & & \\
\hline \multirow[t]{2}{*}{ Reduces my stress } & 1 & 101 & 59.4 & 38 & 22.4 & 31 & 18.2 & & & \multirow[t]{2}{*}{2} \\
\hline & 2 & 28 & 34.6 & 26 & 32.1 & 27 & 33.3 & & & \\
\hline \multirow{2}{*}{ Helps bowel movement } & 1 & 21 & 12.4 & 46 & 27.1 & 103 & 60.6 & \multirow[t]{2}{*}{106} & \multirow[t]{2}{*}{.948} & \multirow[t]{2}{*}{2} \\
\hline & 2 & 9 & 11.1 & 23 & 28.4 & 49 & 60.5 & & & \\
\hline \multirow{2}{*}{ Reduces my fatigue } & 1 & 14 & 8.2 & 58 & 34.1 & 98 & 57.6 & \multirow{2}{*}{1.551} & \multirow{2}{*}{.461} & \multirow[t]{2}{*}{2} \\
\hline & 2 & 10 & 12.3 & 23 & 28.4 & 48 & 59.3 & & & \\
\hline \multirow[t]{2}{*}{ Lowers the blood pressure } & 1 & 131 & 77.1 & 13 & 7.6 & 26 & 15.3 & \multirow[t]{2}{*}{58.583} & \multirow[t]{2}{*}{$.000^{*}$} & \multirow[t]{2}{*}{2} \\
\hline & 2 & 22 & 27.2 & 14 & 17.3 & 45 & 55.6 & & & \\
\hline \multirow{2}{*}{$\begin{array}{l}\text { Helps me concentrate when } \\
\text { studying }\end{array}$} & 1 & 70 & 41.2 & 39 & 22.9 & 61 & 35.9 & \multirow[t]{2}{*}{6.511} & \multirow[t]{2}{*}{$.039^{*}$} & \multirow[t]{2}{*}{2} \\
\hline & 2 & 20 & 24.7 & 23 & 28.4 & 38 & 46.9 & & & \\
\hline \multirow[t]{2}{*}{ Decreases my depression } & 1 & 101 & 59.4 & 27 & 15.9 & 42 & 24.7 & \multirow[t]{2}{*}{11.056} & \multirow[t]{2}{*}{$.004 *$} & \multirow[t]{2}{*}{2} \\
\hline & 2 & 30 & 37.0 & 19 & 23.5 & 32 & 39.5 & & & \\
\hline \multirow[t]{2}{*}{ When I work out } & 1 & 20 & 11.8 & 41 & 24.1 & 109 & 64.1 & \multirow[t]{2}{*}{1.783} & .410 & 2 \\
\hline & 2 & 14 & 17.3 & 21 & 25.9 & 46 & 56.8 & & & \\
\hline
\end{tabular}

$* \mathrm{p}<0.05$,

1: Female, 2: Male

Table 3. T-test results by gender for considerations when buying chocolate

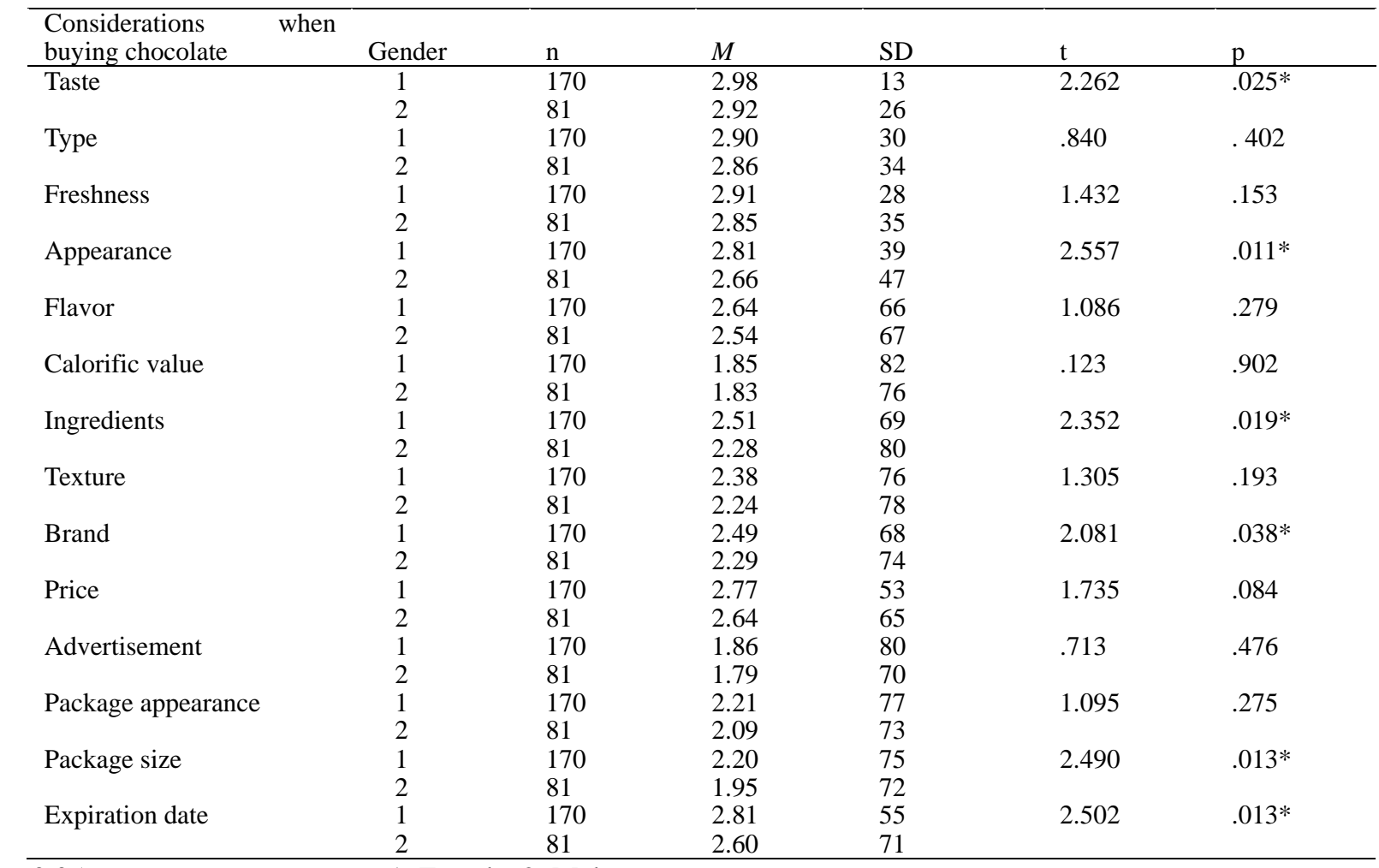

$* \mathrm{p}<0.05$,

1: Female, 2: Male 
As shown in Table 3, the female prospective teachers $(M=2.98)$ had a greater mean score in attention to taste than the male prospective teachers $(M=2.92)$, with a statistically significant difference between groups $(\mathrm{p}<0.05)$. The female prospective teachers $(M=2.81)$ had a greater mean score in attention to appearance than the male prospective teachers $(M=2.66)$, with a statistically significant difference between groups $(\mathrm{p}<0.05)$. The female prospective teachers $(M=2.51)$ had a greater mean score in attention to ingredients than the male prospective teachers $(M=2.28)$, with a statistically significant difference between groups $(\mathrm{p}<0.05)$. The female prospective teachers $(M=2.49)$ had a greater mean score in attention to brand than the male prospective teachers $(M=2.29)$, with a statistically significant difference between groups $(\mathrm{p}<0.05)$. The female prospective teachers $(M=2.20)$ had a greater mean score in attention to package size than the male prospective teachers $(M=1.95)$, with a statistically significant difference between groups $(\mathrm{p}<0.05)$.

Table 4. Chi-square test results by gender for consumption frequency of different chocolate types

\begin{tabular}{|c|c|c|c|c|c|c|c|c|c|c|}
\hline \multirow[b]{2}{*}{ Chocolate type } & \multirow[b]{2}{*}{ Gender } & \multicolumn{2}{|l|}{ Often } & \multicolumn{2}{|c|}{ Sometimes } & \multicolumn{2}{|l|}{ Never } & \multirow[b]{2}{*}{$x^{2}$} & \multirow[b]{2}{*}{ SD } & \multirow[b]{2}{*}{$\mathrm{p}$} \\
\hline & & $\mathrm{n}$ & $\%$ & $\mathrm{n}$ & $\%$ & $\mathrm{n}$ & $\%$ & & & \\
\hline \multirow[t]{2}{*}{ Milk chocolate } & 1 & 10 & 10.8 & 48 & 50.1 & 112 & 109.0 & .726 & 2 & .695 \\
\hline & 2 & 6 & 5.2 & 26 & 23.9 & 49 & 52.0 & & & \\
\hline \multirow[t]{2}{*}{ Dark chocolate } & 1 & 42 & 47.4 & 64 & 73.1 & 64 & 49.4 & 18.740 & 2 & $.000 *$ \\
\hline & 2 & 28 & 22.6 & 44 & 39.9 & 9 & 23.6 & & & \\
\hline \multirow[t]{2}{*}{ White chocolate } & 1 & 64 & 58.9 & 69 & 74.5 & 37 & 36.6 & 2.629 & 2 & .269 \\
\hline & 2 & 23 & 28.1 & 41 & 35.5 & 17 & 17.4 & & & \\
\hline \multirow[t]{2}{*}{ Chocolate with fruit } & 1 & 54 & 53.5 & 84 & 87.4 & 32 & 29.1 & 1.297 & 2 & .523 \\
\hline & 2 & 25 & 25.5 & 45 & 41.6 & 11 & 13.9 & & & \\
\hline \multirow{2}{*}{$\begin{array}{l}\text { Chocolate with } \\
\text { mixed nuts }\end{array}$} & 1 & 22 & 22.4 & 50 & 58.9 & 98 & 88.7 & 7.210 & 2 & $.027 *$ \\
\hline & 2 & 11 & 10.6 & 37 & 28.1 & 33 & 47.3 & & & \\
\hline \multirow[t]{2}{*}{ Flavored chocolate } & 1 & 52 & 53.5 & 62 & 71.8 & 56 & 44.7 & 13.120 & 2 & $.001 *$ \\
\hline & 2 & 27 & 25.5 & 44 & 34.2 & 10 & 21.3 & & & \\
\hline Liquor-filled & 1 & 128 & 115.8 & 22 & 34.5 & 20 & 19.6 & 18.103 & 2 & $.000 *$ \\
\hline chocolate & 2 & 43 & 55.2 & 29 & 16.5 & 9 & 9.4 & & & \\
\hline
\end{tabular}

$* \mathrm{p}<0.05$,

1: Female, 2: Male

Table 4 revealed a statistically significant difference between the female and male prospective teachers in the consumption frequency of dark chocolate, chocolate with nuts, flavored chocolate and liquor-filled chocolate $\left(\mathrm{x}^{2}=18.740, \mathrm{x}^{2}=7.210, \mathrm{x}^{2}=13.120, \mathrm{x}^{2}=18.103\right.$, respectively, $\left.\mathrm{SD}=2, \mathrm{p}<0.05\right)$.

\section{Discussion}

This study was planned and carried out to determine the chocolate consumption habits of prospective teachers. The study results revealed that the prospective teachers preferred to eat chocolate according to its creaminess, milk content, smooth texture, cocoa content and crispiness, respectively. Ozdogan (2008) reported that university students preferred to eat milk chocolate, chocolate with mixed nuts and chocolate with pistachio the most, in order of preference. The study results showed that the prospective teachers mostly preferred to use chocolate in the making of cookies, cakes and ice cream, whereas very few consumed it as hot chocolate. In their study, Vicenta, Sandra, Rabanal, Rodriguez-Lagunas, Pereira, P., Perez-Cano (2016) found that the students preferred to consume chocolate in the form of pastries and desserts, as well as, in cereals, while very few preferred to drink hot chocolate.

Although the majority of the female and male prospective teachers agreed with the statement chocolate consumption is good for cardiovascular diseases, the female prospective teachers had a higher rate of agreement. Various studies reported that the catechins in cocoa could decrease the incidence of cardiovascular diseases with a 70-90 g daily consumption of dark chocolate (Gibble, 2011; Martin, Goya \& Ramos, 2013; Kwok, et al., 2015; Gibble, 2016). However, other studies reported that, with the coexistence of multiple factors such as age, gender, lifestyle including dietary data, cigarette use and insufficient physical activity, chocolate consumption did not have a significant effect on the reduction of the incidence of cardiovascular diseases (Koli, et al., 2015; Kwok, et al., 2016). According to the results of the present study, the female prospective teachers were more conscious about the possibility of a relationship between chocolate consumption and cardiovascular diseases than the male prospective teachers, although they both attended university.

While the majority of the female prospective teachers agreed with the statement eating chocolate reduces my stress, only a minority of the male prospective teachers expressed agreement. Various studies indicate regular consumption of flavonoid-rich cocoa supports cognitive functions, reduces stress and improves mental health (Allgrove, et al., 2011; Crichton, Elias \& Alkerwi, 2016). Markus (2002) reported the consumption of dark chocolate had a calming effect and reduced depression by causing the brain to produce serotonin. Meier et al. (2017) identified an improvement in positive mood after chocolate consumption. According to the results of the present study, the higher chocolate consumption in the female prospective teachers compared to the male prospective teachers during periods of stress and unhappiness 
could be attributed to the increase in positive mood with the consumption of chocolate. The majority of the female and male prospective teachers disagreed with the statement chocolate consumption lowers the blood pressure. Latham, Hensen, \& Minor (2014) reported that, with the consumption of food rich in cocoa, flavanols lowered blood pressure by inhibition of angiotensin-converting enzyme. Another study reported that daily consumption of flavanol-rich cocoa products lowered blood pressure (Desch, Schmidt, Kobler, Sonnabend, Eitel, et al., 2010). However, another study suggested that cocoa in chocolate did not lower blood pressure (Koli et al., 2015). The disagreement of the majority of the prospective teachers with the statement chocolate consumption lowers the blood pressure might be due to their inadequate knowledge of the subject. However, the higher rate of agreement of the female prospective teachers could be attributed to their greater interest in and knowledge of both health and nutrition, in comparison to the male prospective teachers. The majority of the female prospective teachers and approximately half of the male prospective teachers agreed with the statement eating chocolate reduces my depression, while approximately half of the female and male prospective teachers disagreed. Ozdogan (2008) reported that students ate chocolate because of the feeling of happiness it induced. In addition, Meier et al. (2017) identified increased positive mood and decreased depression in students after chocolate consumption. In this case, it is possible to postulate that female prospective teachers consumed a greater amount of chocolate when depressed in order to feel happy.

The female prospective teachers scored higher than the male prospective teachers in attention to taste, appearance, percent ingredients and brand when buying chocolate. Dilber \& Dilber (2013) similarly reported that students were primarily attentive to the food label and nutrition facts when buying chocolate. In another study conducted by Tasci (2016), the participants reported that, when buying a chocolate product, they chose the product according to the brand, nutrition content, packaging color and price. This result shows that the female prospective teachers had a greater interest in food products and were more attentive to the food label and nutrients. The female prospective teachers had a greater mean score in attention to package size than the male prospective teachers. This led the researcher to postulate that, in comparison to the male prospective teachers, the female prospective teachers believed food products with larger packages were more economical and shopped accordingly. The female prospective teachers ate dark chocolate, chocolate with mixed nuts, flavored chocolate and liquor-filled chocolate more frequently than the male prospective teachers. Pazarbasi et al. (2015) found that dark chocolate was preferred because it gave greater satiety than milk chocolate. Vicenta, et al. (2016) similarly reported that the majority of the university students consumed dark chocolate more frequently than milk chocolate. In the present study, the female participants had more accurate opinions on the contents of various types of chocolate in comparison to the male participants.

\section{Conclusion}

The female prospective teachers had a greater chocolate consumption, and were more conscious and attentive in their consumption of chocolate and other food products than the male prospective teachers. Milk and cocoa content were the most desired properties in chocolate. In comparison to the male prospective teachers, the majority of the female prospective teachers agreed with the statements good for cardiovascular diseases, lowers the blood pressure, reduces my depression and reduces my stress, while a minority of the male prospective teachers disagreed. The female prospective teachers were more conscious and informed than the male prospective teachers, and were more attentive to taste, appearance, ingredients, brand and package size when buying chocolate.

In conclusion, the female prospective teachers were more attentive and conscious in comparison to the male prospective teachers. The prospective teachers could be informed on daily chocolate consumption and its effects on health, in order to raise their awareness. The food industry could promote particularly dark chocolate consumption through colorful/attractive packaging and advertisements. In addition, further studies could be conducted with larger samples and with the participation of middle and older age groups.

\subsection{The limitations of this Study Are as Follows}

This study only investigated the properties prospective teachers sought in their chocolate consumption with respect to gender. However, future studies could investigate the properties of chocolate individuals who have and have not received nutrition education desired, thus researching the difference with respect to whether or not individuals have received nutrition education.

The reasons for the consumption of chocolate among prospective teachers were only investigated with respect to gender. However, future studies could focus on other factors such as age, cigarette consumption and blood pressure, together with gender.

This study was limited to the chocolate consumption of the students of the Faculty of Education. However, future studies could investigate the difference in dark chocolate consumption between students attending the Faculty of Health Sciences and those attending the Faculty of Education. This would allow the identification of the opinions of health sciences students regarding the positive and negative health effects of dark chocolate consumption. 


\section{Acknowledgements}

I would like to thank all undergraduate prospective teachers who participated in this study and the deanship of faculty.

\section{References}

Alkerwi, A., Sauvageot, N., Crichton, G. E., Elias, M. F., \& Stranges, S. (2016). Daily chocolate consumption is inversely associated with insulin resistance and liver enzymes in the Observation of Cardiovascular Risk Factors in Luxembourg study. Br. J. Nut., 115, 1661-1668. https://doi.org/10.1017/S0007114516000702

Allgrove, J., Farrell, E., Gleeson, M., Williamson, G., \& Cooper, K. (2011). Regular Dark Chocolate Consumption's Reduction of Oxidative Stress and Increase of Free-Fatty-Acid Mobilization in Response to Prolonged Cycling. Int. J. Sport Nutr. Exerc. Metab., 21(2), 113-123. https://doi.org/10.1123/ijsnem.21.2.113

Anonymous. (2012). Use of Chocolate Confectionery Products, Food and Beverage Services, T.C. Ministry of Education, Ankara.megep.meb.gov.tr/pdf/pd. Acces Date 23/07/2016. Acces Time: 17:00.

Beckett, S. (2008). The Science of Chocolate, RSC Adv. ISBN: 978-0-85404-970-7. York, UK.

Crichton, E. G., Elias, F. M., \& Ala'a, A. A. (2016). Chocolate intake is associated with better cognitive function: The Maine-Syracuse Longitudinal Study. Appetite, 100, 126-132. https://doi.org/10.1016/j.appet.2016.02.010

Desch, S., Schmidt, J., Kobler, D., Sonnabend, M., Eitel, I., Sareban, M., ... Thiele, H. (2010). Effect of cocoa products on blood pressure: systematic review and meta-analysis. Am. J. Hypertens, $23,97 \mathrm{e} 103$. https://doi.org/10.1038/ajh.2009.213

di Giuseppe, R., Castelnuovo, D. A., Centritto, F., Zito, F., Curtis, D.A., Costanzo, S., ... Iacoviello, L. (2008). Regular consumption of dark chocolate is associated with low serum concentrations of C-reactive protein in a healthy Italian population. J. Nutr., 138, 1939e45.

Dilber, F., \& Dilber, A. (2013). The Effect of Media on Universtiy Students' Food Products Consumption: A Research on Karamanoglu Mehmet Bey Universtiy, Gumushane University E-Journal of Faculty of Communication, 1(2), 64-82.

Farid, Z., Njike, V.Y., Dutta, S., Ali, A., \& Katz, D. L. (2008). Acute dark chocolate and cocoa ingestion and endothelial function: a randomized controlled crossover trial. Am. J. Clin. Nut., 88(1), 58-63.

Farzanmehr, H., \& Abbasi, S. (2012). Effect of inulin and bulking agents on some physicochemical, textural and sensory properties of milk chocolate. Journal of Taibah University Medical Sciences, 9(4), 341-344.

Gibble S. (2011). How to relieve constipation with cocoa. Available from url: http://www.associatedcontent.com/article/1149686/ how_to_relieve_constipation_with_cocoa.html. Accessed 29 October 2016.

Gibble, S. (2016). How to relieve constipation with cocoa? Available from url:http://www.associatedcontent.com/article/1149686/how_to_relieve_constipation_with_coco.html Accessed: 17July 2016.17:00.

Grassi, D., Desideri, G. S., Necozione, S., Ruggieri, F., Blumberg, J.B., Stornello, M., \& Ferri, C. (2012). Protective Effect of Flavanol-Rich Dark Chocolate on Endothelial Function and Wave Reflection During Acute Hyperglycemia. Hypertension, 60(3), 827-832. https://doi.org/10.1161/Hypertensionaha.112.193995

Greenberg, J. A. (2015). Chocolate intake and diabetes risk. Clin. Nutr., 34, $129-133$. https://doi.org/10.1016/j.clnu.2014.02.005

Greenberg, J. A., \& Buijsse, B. (2013). Habitual chocolate consumption may increase body weight in a dose-response manner. PLoS One., 8, e70271. https://doi.org/10.1371/journal.pone.0070271

Hermann, F., Spieker, L. E., Ruschitzka, F., Sudano, I., Hermann, M., Minggeli, C., .. Corti, R. (2006). Dark chocolate improves endothelial and platelet function. Heart, 92, 119e20. https://doi.org/10.1136/hrt.2005.063362

Katz, D. L., Doughty, K., \& Ali, A. (2011). Cocoa and chocolate in human health and disease. Antioxid Redox Signal. Epub., 15(10), 2779-2811.

Kaya, A., \& Sekeroglu, G. (2012). Chocolate, Turkish Standart Institution Journal, 604, 23-25.

Kerimi, A., \& Williamson, G. (2015). The cardiovascular benefits of dark chocolate. Vascul. Pharmacol, $71,11-5$. https://doi.org/10.1016/j.vph.2015.05.011

Koli, R., Köhler, K., Tonteri, E., Peltonen, J., Tikkanen, H., \& Fogelholm, M. (2015). Dark Chocolate and reduced snack consumption in mildly hypertensive adults: an intervention study. Nutr. J., 14 , 84. 
https://doi.org/10.1186/s12937-015-0075-3

Kwok, C. S., Boekholdt, S. M., Loke, Y. K., Lentjes, M., Luben, R.N., Yeong, J. K., ... Khaw, K. T. (2015). Habitual chocolate consumption and risk of cardiovascular disease among healthy men and women. Heart, 101, 1279-1287. https://doi.org/10.1136/heartjnl-2014-307050

Kwok, C. S., Loke, Y. K., Welch, A. A., Luben, R. N., Lentjes, M., Boekholdt, S. M..,...Myint, P. K. (2016). Habitual chocolate consumption and the risk of incident heart failure among health men and women. Nutr. Metab. Cardiovasc. Dis., 20, 1-13.

Latham, L. S., Hensen, Z. K., \& Minor, D. S. (2014). Chocolate e guilty pleasure of healthy supplement. J. Clin. Hypertens. (Greenwich), 16, 101e6. https://doi.org/10.1111/jch.12223

Lilamand, M., Kelaiditi, E., Guyonnet, S., Antonelli Incalzi, R., Raynaud-Simon, A., Vellas, B., \& Cesari, M. (2014). Flavonoids and arterial stiffness: promising perspectives. Nutr. Metab. Cardiovasc. Dis., 24, 698-704. https://doi.org/10.1016/j.numecd.2014.01.015

Markus, C. R. (2002). New insight in the beneficial effect of food on mood and performance: evidence for interference between stress and brain 5 HT. Agro Food Ind. Hi Tech., 13(5), 21-23.

Martin, M. A., Goya, L., \& Ramos, S. (2013). Potential for preventive effects of cocoa and cocoa polyphenols in cancer. Food Chem. Toxicol., 56, 336-351. https://doi.org/10.1016/j.fct.2013.02.020

Meier, B. P., Noll, S.W., \& Molokwu, O. J. (2017). The sweet life: The effect of mindful chocolate consumption on mood. Appetite, 108, 21-27. https://doi.org/10.1016/j.appet.2016.09.018

Ozdogan, E. N. (2008). A Survey Research on the Young Consumer' Preferences for Chocolate Consumption, NWSA. 3(1), h160-161. http://www.newwsa.com/download/NWSA-570-394-2.pdf. Access date:17/07/2016.Acces time: 17:00.

Ozgen, L. (2004). Food Label Reading Habits of Consumers, Nutrition Label and Packaging Preferences Related Factors (Unpublished doctoral dissertation). University of Gazi Education Science Faculty, Instution of Education Sciences, Ankara.

Pazarbasi, I. (2015). Effect on Healthy Individuals Bitter Chocolate Blood Glucose and Insulin Levels (Unpublished master's thesis). University of Hacettepe Health Sciences Instution, Nutrition Sciences Programs, Ankara.

Scholey, A., \& Owen, L. (2013). Effects of chocolate on cognitive function and mood; a systematic review. Nut. Rev., $71(10), 665-681$. https://doi.org/10.1111/nure.12065

Sokmen, A. (2005). Effects of sucrose substitute chocolate Rheological Properties of Some (Unpublished master's thesis). Istanbul Technical University, Science Instutions, Istanbul.

Tasci, A. D. A. (2016). A critical review of consumer value and its complex relationships in the consumer-based brand equity network. Journal of Destination Marketing \& Management, 5, 171-191. https://doi.org/10.1016/j.jdmm.2015.12.010

Vicente, F., Sandra, S. R., Rabanal, M., Rodriguez-Lagunas, M. J., Pereira, P., Perez-Cano, F. J., \& Castell, M. (2016). A new food frequency questionnaire to asses chocolate and cocoa consumption. Nutrition, 32, 811-817. https://doi.org/10.1016/j.nut.2016.01.027 